\title{
Glossary and conventions
}

\author{
Abbreviations \\ AECP La Courneuve, Paris, Affaires Étrangères, \\ Correspondence Politique (Angleterre) \\ AUL Aberdeen University Library, Special Collections \\ BL British Library \\ HMC Historical Manuscripts Commission \\ MS Carte Bodleian Library, Oxford, Carte Papers \\ NLS National Library of Scotland \\ NRS National Records of Scotland \\ Stuart Papers Royal Archives, Windsor, Stuart Papers
}

\section{Dates, spelling and punctuation}

Until the adoption of the Gregorian calendar on 2 September 1752 the British Isles used the Julian calendar, which was ten days behind the rest of Europe (except Russia) in the seventeenth century and eleven days behind in the eighteenth century. All dates given below up to 2 September 1752 are therefore either ten or eleven days behind most of their European counterparts, but with the beginning of the year dated from 1 January rather than $25 \mathrm{March}$, the official date of the new year in the three kingdoms (England, Ireland and Scotland) up to 1751. All of the correspondence and documents cited below stemming from continental locations has therefore had the old-style, British Isles, date added in the following form: 6/17. Thus a letter written in Paris on 14 May 1745 would be cited below as having been written on 3/14 May 1745 .

The spelling and punctuation of all quotations and documents have been modernised wherever this helps elucidate the meaning 
of the text. Commonplace contractions and abbreviations have all been silently expanded.

\section{Nomenclature}

Throughout the second edition of this book I refer to the son of King James II of England and VII of Scotland as James III and VIII. This is not intended as any kind of political statement, but as a simple recognition of a fact: he was the legitimate and oldest son of the reigning king at the time of his birth and was proclaimed Prince of Wales shortly afterwards. He was also at various times recognised as a genuine king by most of the great powers of Europe and a large minority of the population in the British Isles. The only reason he was ever dubbed 'the Pretender' by post-Revolutionary Parliaments was silently to impugn his claim to the throne after he was retrospectively excluded from the succession by laws passed by those same Parliaments. The original grounds for this exclusion (and in part for his father's deposition) was that King William III and II's supporters claimed that the new-born Prince of Wales was not the son of James II and VII, but a 'suppositious child' smuggled into the royal bedchamber in a warming-pan. This, they asserted, was the culmination of a Catholic conspiracy by which the allegedly impotent/diseased King James would be provided with a male heir who would in due course persecute Protestants throughout the British Isles in order to force their conversion to Catholicism.

In contemporary terms this conspiracy theory was necessary to justify the invasion of England and the overthrow of King James by William, Prince of Orange, and a Dutch army supported by armed uprisings by Englishmen of all ranks of society across the whole of the country. This was because a rebellion in support of a foreign invader was an affront to English national pride and went directly against the teachings of the Church of England, the church regularly attended by the great majority of the population. Only the most real and present danger to Protestantism and the Church of England could justify such an egregious sin. The entire warming-pan story was, however, completely false. ${ }^{1}$ To use modern terminology, it was fake news.

As was customary, James III and VIII's birth was witnessed by dozens of nobles and courtiers (Protestant and Catholic) from all over the British Isles, to say nothing of servants, midwives and sol- 
diers standing guard. And even though he used the story to justify his seizure of the throne King William himself did not believe it, as he showed when he secretly discussed with Louis XIV taking the Prince of Wales as his heir. The proposal came to nothing because James II and VII refused to allow his son to become ' $a[c]$ complice to his unjust dethronement', but the fact that William entertained it at all is telling. ${ }^{2}$

Thus what happened in the winter of 1688-9 was the overthrow of one king of England (he was not deposed in Ireland and Scotland until later) and his replacement by another, retrospectively endorsed by Acts of Parliament. This was nothing exceptional in English history: leaving aside the bloody family politics of the Norman and Angevin kings, Edward II was deposed in favour of Edward III, Henry IV seized the throne from Richard II, Edward IV overthrew Henry VI (twice), Richard III deposed Edward V, and Henry VII defeated and killed Richard III. Each of these usurpations was retrospectively endorsed and legitimised by Acts of Parliament. Yet historical orthodoxy has had little problem in recognising the titles of all these monarchs, no matter whether they were actually crowned or not (viz. Edward V). Charles I and Charles II were also unkinged by a Parliament, yet they are still accorded their titles even, as in Charles II's case, when they had been legally deposed by a revolutionary Parliament and were in exile.

My use of the title James III and VIII to designate the son of James II and VII is, then, a pragmatic statement accurately identifying a particular historical actor. From a dispassionate historical perspective we can see that there were two royal lines claiming the right to rule the British Isles between 1688 and 1807, each basing its claim on precedent and law. The first, the Catholic Stuart line, was directly descended by blood from James II and VII, an anointed, consecrated and fully recognised king, who never abdicated (Parliament claimed he had in 1689, but this was a legal fiction) and only ended in 1807 when Cardinal Henry Benedict Stuart died. The second, the Protestant Stuart line from 1688 to 1714 and the Guelf or Hanoverian line from 1714 to 1901, was legally endorsed by multiple acts of multiple Parliaments and thus had at least as much right to reign as the Lancastrian, Yorkist or Tudor dynasties. It also had the inestimable advantage of actually being in possession of real power, in London. Monarchs in both lines of succession were, furthermore, at various times recognised 
by most of the great powers of Europe, that is, they were acknowledged to be part of the princes club. This only ended with the death of James III and VIII on 1 January 1766. Thereafter nobody other than a handful of ageing Jacobite diehards recognised Charles Edward Stuart or Henry Benedict, both legitimate sons of James III and VIII, as Charles 'III' or Henry 'IX'. Hence I shall refer to them only by their names and Jacobite titles (i.e. Jacobite Prince of Wales and Jacobite Duke of York).

I shall also use this form of nomenclature when referring to other individuals with titles granted by the exiled Stuarts. Following on from the two lines of succession, over time there came to be two strands in the peerages of the three kingdoms. Thus, for example, in 1715 James III and VIII created John Erskine, Earl of Mar, Jacobite Duke of Mar. Since Mar was subsequently attaindered by the British Parliament he became no peer at all in territories ruled by the British state. But he was still recognised as a peer (indeed, as a duke) by James's supporters in the British Isles and the European great powers with whom he came into contact. Where necessary I shall therefore refer to him as the Jacobite Duke of Mar.

\section{Notes}

1 As Professor Murray Pittock has convincingly argued, terms such as 'the Pretender' are 'based on a lie concerning his birth' (Pittock, Culloden (Cùil Lodair) (Oxford, 2016), p. xiii), which modern historians do not need to accept.

2 J. S. Clarke (ed.), The Life of James the Second, King of England, \&c, Collected Out of Memoirs Writ of His Own Hand (2 vols, London, 1816), ii. 574-5. James subsequently regretted his decision to spurn the proposal. 